towards pedagogical activity; self-realization, pedagogical activity. Recently the issue of creativity has been the subject of researches of many specialists in various fields of Psychology. The works of scientists studying the psychological mechanisms of creativity (L. Vygotsky, N. Guzii, V. Eliseev, I. Kogan, V. Moliako, Ya. Ponomarev, S. Rubinstein and others) have been reviewed. The problems of young teachers' creativity in the psychological and pedagogical aspects have been described. It has been stated that the creative process involves going beyond that is directly deduced from the existing theoretical claims and concrete experience. Besides, the results of the survey concerning the issue of creativity have been presented, in which 120 teachers of secondary schools of Poltava and Poltava region have taken part. As a result of the survey it has been found that a large number of respondents believe that the basis of the creative process is empathy, creativity, self-dependence, and perseverance.

Keywords: creativity, creative process, beginning teacher, development, psychological conditions, professional becoming, professional activity.

Подано до редакизії 04.02.2016

Рецензент: д. психол. н., проф. С. П. Яланська

UDC: $159.923+001.8+159.9$

Olha Tsarkova,

PhD (Candidate of Psychological Sciences), associate professor, Department of Psychology,

Olesia Prokofieva,

PhD (Candidate of Psychological Sciences), associate professor, Department of Psychology,

Olha Prokofieva,

senior lecturer, Department of Human and Animal Anatomy and Physiology,

Melitopol State Pedagogical University named after Bohdan Khmelnytskyi,

20, Lenina Str., Melitipol, Ukraine,

\title{
THE STUDY OF EMOTIONAL BURNOUT IN STUDENTS-PSYCHOLOGISTS AND PROFESSIONAL PSYCHOLOGISTS
}

The paper presents the results of the empirical study conducted with the aim of determining the level of emotional burnout among students-psychologists and professional psychologists. Harmful effect of emotional burnout syndrome on human health is described. The study has shown that 30\% of professional psychologists demonstrated high level of emotional burnout and among 30\% of them the level of emotional burnout was higher than average. As for studentspsychologists, $10 \%$ of them are characterized by high level of emotional burnout.

Keywords: emotional burnout syndrome, students-psychologists, professional psychologists, stress, emotional burnout symptoms.

Problem statement. Research of emotional burnout syndrome is relevant as long as any person may suffer from it. Burnout is a response to long term stress in interpersonal communication. Profit motives, not always properly organized work with staff and customers, organizational and professional stress and many other factors influence the development of this syndrome, which results in the state of emotional, mental and physical exhaustion.

The article is aimed at identifying the level of emotional burnout of professional psychologists and studentspsychologists.

Review of recent research and publications. The concept of emotional burnout syndrome was introduced in psychology by the American psychiatrist H. J. Freudenberger in 1974 to denote growing emotional exhaustion. This syndrome is identified by him as overwork. H. J. Freudenberger pointed out that this condition is peculiar to people prone to empathy, idealistic attitude to work, and, at the same time, prone to dreaming, obsessed with fixed ideas. In this case, emotional burnout syndrome can be represented as a psychological defense mechanism in the form of partial or complete absence of emotions in response to psychotraumatic exposure.

The phenomenon of emotional burnout was specified by K. Maslach, B. Perlman and E. A. Hartman in 1982. They identified three main components of burnout: emotional and /or physical exhaustion, depersonalization and reduced work efficiency $[6 ; 7 ; 8]$.

A. Pines with his colleagues associated burnout with a sense of self-importance at work, professional advancement, autonomy and control by management. At the same time, dissatisfaction with professional growth, the need for support, lack of autonomy may cause this syndrome. 
V. I. Kovalchuk emphasizes the role of such personal characteristics as self-esteem and locus of control. People with low self-esteem and external locus of control are more vulnerable and prone to burnout.

K. Kondo considers that workaholics who devote themselves to work and achieve goals at any price are most vulnerable to emotional burnout syndrome.

Major content. Emotional burnout is a psychological defense mechanism in the form of partial or complete absence of emotions in response to psychotraumatic exposure. Burnout syndrome is a process of gradual loss of emotional, cognitive and physical energy, manifested in symptoms of emotional, mental exhaustion, physical fatigue, alienation and reduced personal satisfaction with work performance $[1 ; 2]$.

There are a great number of emotional burnout symptoms. People suffering from emotional burnout syndrome, as a rule, demonstrate a combination of psychopathologic, psychosomatic, somatic symptoms and signs of social dysfunction manifested as chronic fatigue, cognitive dysfunction (disturbance of memory, attention), sleep disturbances, personality changes, anxiety and depressive disorders, psychoactive substance dependence, suicide attempts. The general somatic symptoms of emotional burnout include headache, gastrointestinal (diarrhea, irritable stomach syndrome) and cardiovascular (tachycardia, arrhythmia, hypertension) disturbances. We can also highlight five key groups of symptoms of emotional burnout syndrome: physical symptoms; emotional symptoms; behavioral symptoms; intellectual condition; social symptoms [3; 9].

The main factors that play a significant role in emotional burnout include the following ones: personal, role and organizational. Personal factors include: proneness to compassion, idealistic attitude to work together with instability, proneness to dreams, obsession with fixed ideas; empathy, humanness, gentle manner, proneness to be fascinated, idealization, introversion, fanaticism. Role factor is revealed in role proneness to conflict, role indeterminacy. Organization factor involves demanding hours-long work, which is not appreciated and requires exceptional productivity; inappropriate content of work, type of management, overstress and excessive amount of work, especially with unrealistic deadlines for its implementation; monotonous work; allocating considerable personal resources and lack of recognition and positive evaluation; physical exhaustion, insufficient rest or lack of normal sleep; work without further professional development; tensions and conflicts in interpersonal relationships; lack of support from colleagues; emotional abundance or cognitive difficulty of communication, etc.etc.

A study was conducted in order to diagnose emotional burnout syndrome in third-fourth-year students majoring in psychology of Humanities Faculty of Novokuznetsk Institute (branch) "Kemerovo State University" and professional psychologists working at one of the centers of Novokuznetsk. There were 24 students aged 19 to 21 who participated in the study, including 3 boys and 32 girls:

$$
\begin{aligned}
& 3^{\text {rd }} \text { year }-14 \text { people aged } 19-20 \text { including } 3 \text { boys and } \\
& 11 \text { girls; } \\
& 4^{\text {th }} \text { year }-10 \text { people aged } 20-21 \text {, girls only; } \\
& \text { As for professional psychologists, } 10 \text { women aged }
\end{aligned}
$$
27 to 50 have been examined with the experience of 5 years ( 3 people), 20 years ( 4 people), 25 years ( 3 people).

Identification of emotional burnout symptoms showed that tension in professional psychologists was manifested as follows (the average score was 30.8 points): $60 \%$ of the surveyed had immature phase; $40 \%$ of study participants demonstrated forming phase. The average score in the group of people with the symptom of experiencing traumatic circumstances was 11.4 points. $50 \%$ of surveyed possessed mature symptom; $20 \%$ demonstrated complex nature of this symptom; $30 \%$ showed signs of mature symptom. The average score in the group of participants with a symptom of dissatisfaction with oneself was 4.7 points. Thus, $70 \%$ of the patients possessed immature symptom; in $20 \%$ of the participants the symptom was of complex nature and in $10 \%$ of the surveyed the symptom was prevailing. The average score in the group of people with symptoms of "being caged" was 7.2 points. In this context, $70 \%$ of the surveyed demonstrated mature symptom; $20 \%$ of study participants noted its complex nature and in $10 \%$ of the surveyed this symptom was dominating. The average score in the group of study participants with symptoms of anxiety and depression was 7.7 points. In particular, $70 \%$ of the surveyed demonstrated mature symptom, and $30 \%$ of them demonstrated complex nature of this symptom.

Resistance in professional psychologists was manifested as follows: the average score in the group of respondents was 43.3 points. Amongst $30 \%$ of the surveyed this symptom was immature; $60 \%$ of them noted that it was in the process of forming; $10 \%$ of the study participants demonstrated "resistance" phase formed. The average score in the group of professional psychologists with the symptom of inadequate selective emotional response was 14.1 points. $20 \%$ of the study participants were characterized by immature phase of this symptom; in $40 \%$ of respondents it was of complex nature; $10 \%$ demonstrated mature symptom and among $30 \%$ of the study participants this symptom was dominant. The average score in the group of study participants with symptoms of emotional and moral disorientation was 9.7 points. Among $40 \%$ of the respondents this symptom was immature; $40 \%$ demonstrated its complex nature; in $10 \%$ of the surveyed the symptom was formed and among $10 \%$ of them it was dominant. The average score in the group of psychologists showing the symptoms of expanding the sphere of emotional thriftiness was 6.5 points: $90 \%$ of them had mature symptom and in $10 \%$ of psychologists the symptom was dominant. The average score in the group of psychologists with the symptom of reduction of professional capacity was 13 points. In particular, $40 \%$ of the surveyed had immature symptom; $10 \%$ of them had the symptom of complex nature; $30 \%$ of psychologists had mature symptom and in $20 \%$ of them the symptom was dominant.

Exhaustion in professional psychologists was ex- 
pressed as follows (the average score was 27.4 points): among $10 \%$ of the surveyed this symptom was in the process of forming while in $90 \%$ of cases it was at immature phase. The average score in the group of psychologists examined for symptoms of emotional deficit was 8.5 points. In particular, amongst $70 \%$ of the study participants the symptom was at immature stage; in $20 \%$ of cases the symptom was of complex nature and $10 \%$ of the surveyed demonstrated mature symptom. The average score in the group of professional psychologists with symptoms of emotional detachment was 6.8 points. $70 \%$ demonstrated immature symptom; in $10 \%$ of cases the symptom was of complex nature; $10 \%$ of the surveyed demonstrated mature symptom and in $10 \%$ of them the symptom was dominant. The average score in the group of study participants with symptoms of personal detachment or depersonalization was 7.1 points. In particular, $70 \%$ of the surveyed demonstrated immature symptom, and $30 \%$ of them - the symptom of complex nature. The average score in the group of professional psychologists with symptoms of psychosomatic and psycho-vegetative disorders was 5 points. Thus, $80 \%$ of respondents demonstrated immature symptom and $20 \%$ of them had the symptom of complex nature.

Thus, the study of emotional burnout showed the following levels of emotional burnout in professional psychologists (the average score in the group of respondents was 101.7 points): $30 \%$ of respondents showed a fairly high level of emotional burnout (above 120 points); 30\% of the surveyed demonstrated average and above average levels of emotional burnout (above 100 points); 30\% of study participants were characterized by slightly less than the average level of emotional burnout (above 80 points) and $10 \%$ of them showed relatively low level of emotional burnout (above 50 points).

We have also studied emotional burnout expressiveness in students-psychologists of the group P-05 $\left(4^{\text {th }}\right.$ year). In this student group 10 people have been tested. The results of the study were the following:

The average score according to the level of emotional burnout amounted to 114.1 . In particular, $70 \%$ of the surveyed had a considerably high level of emotional burnout (above 100 points); $10 \%$ of the study participants were characterized by a high level of emotional burnout (above 90 points); $10 \%$ of the surveyed had higher than average level of emotional burnout (above 60 points) and $10 \%$ of them had relatively low level of emotional burnout (above 50 points).

The study of emotional burnout symptoms has shown that tension among students-psychologists was expressed as follows: the average score in the group of the surveyed was 21 points. At the same time, $10 \%$ of the study participants demonstrated that the phase was in the process of forming and in $90 \%$ of cases the phase was immature. The average score in the group of students with symptoms of experiencing traumatic circumstances was 5.1 points. None of the study participants demonstrated this symptom. The average score in the group of students with the symptom of dissatisfaction with oneself was 5.3 points. In particular, among $20 \%$ of the surveyed this symptom was in the process of forming and $80 \%$ of students demonstrated mature symptom. The average score in the group of study participants with the symptom of being caged was 5.2 points. $90 \%$ of respondents had mature symptom; among $10 \%$ of students this symptom was dominating. The average score in the group of study participants with the symptoms of anxiety and depression was 5.4 points. In particular, $10 \%$ of the students demonstrated complex nature of this symptom and in $90 \%$ of cases the symptom was not formed.

Resistance in students-psychologists was manifested as follows: the average score was 56 points. $50 \%$ of the surveyed demonstrated mature phase; among $40 \%$ of them it was in the process of forming and in $10 \%$ of cases the phase was immature. The average score in the group of students with symptoms of inadequate selective emotional response was 17.1 points. In particular, among $40 \%$ of respondents the symptom was of complex nature; in $20 \%$ of the surveyed the symptom was formed; $40 \%$ of the students demonstrated the symptom in the dominant phase. The average score in the group of study participants with symptoms of emotional and moral disorientation was 12.5 points. $50 \%$ of respondents had immature symptom, $10 \%$ of them demonstrated the symptom of complex nature, in $10 \%$ of the surveyed the symptom was mature and in $30 \%$ of the surveyed the symptom was in dominant phase. The average score in the group of students with the symptoms of expanding the sphere of emotional thriftiness was 9 points. In particular, $70 \%$ of the group participants demonstrated formed symptom, $10 \%$ of respondents had the symptom of complex nature and $20 \%$ of them demonstrated the symptom in a dominant phase. The average score in the group of students with the symptom of professional duties reduction was 16.4 points. In particular, $10 \%$ of respondents had a mature symptom; $40 \%$ of the surveyed demonstrated symptom of complex nature; $30 \%$ of them had immature symptom and $20 \%$ of the surveyed had the symptom in its dominant phase.

The study of emotional burnout symptoms showed that exhaustion of the students-psychologists was manifested as follows (the average score in the group was 37.1): $70 \%$ of respondents demonstrated immature phase; $10 \%$ of the group participants demonstrated mature phase and in $20 \%$ the phase is in the process of forming. The average score in the group of students with the symptoms of emotional deficit was 10.2 points. $50 \%$ of respondents had mature symptom, $20 \%$ of the surveyed demonstrated the symptom of complex nature and in $30 \%$ of them the symptom was in dominant phase. The average score in the group of study participants showing the symptoms of emotional detachment was 11 points: $40 \%$ of the surveyed had mature symptom, $20 \%$ of respondents demonstrated the symptom of complex nature; $30 \%$ of the students had immature symptom and among $10 \%$ of them the symptom was in dominant phase. The average score in the group of students-psychologists with the symptoms of personal detachment or depersonalization was 8.1 points. In particular, $60 \%$ of respondents had immature 
symptom, $30 \%$ of the surveyed demonstrated the symptom of complex nature and in $10 \%$ of cases the symptom was dominant. The average score in the group of studentspsychologists with the symptoms of psychosomatic and psycho-vegetative disorders was 8.8 points. $60 \%$ of the surveyed had immature symptom, $10 \%$ of them demonstrated the symptom of complex nature, in $20 \%$ of the students demonstrated mature symptom and $10 \%$ of them demonstrated a dominant phase of the symptom.

In the group of third-year students (P-06) 14 students took part in the study. The results of the study were the following.

The average score in the group of students with the symptoms of emotional burnout was 93 points. In particular, $14.28 \%$ of the group demonstrated considerably high level of emotional burnout (above 140 points); 35.7\% of respondents had a high level of emotional burnout (above 100 points); $28.6 \%$ of the patients had a higher than average level of emotional burnout (above 60 points) and $21.42 \%$ of the group had relatively low level of emotional burnout (above 30 points).

The study of emotional burnout symptoms showed that tension among the psychologists-students was expressed as follows: the average score in the group of respondents was 23.9 points. $78.6 \%$ of the surveyed demonstrated forming symptom; $21.4 \%$ had immature phase. The average score in the group of respondents experiencing symptoms of traumatic circumstances was 7.9 points. In particular, $64.3 \%$ of the group participants had mature symptom; $21.4 \%$ demonstrated the symptom of complex nature; in $14.3 \%$ of respondents the symptom was immature. The average score in the group of students with the symptom of dissatisfaction with oneself was 5.4 points. $85.7 \%$ of respondents had mature symptom and in $14.3 \%$ of them had the symptom of complex nature. The average score in the group of students-psychologists with the symptom of being caged was 3.1 points. $92.9 \%$ of respondents had mature symptom and $7.1 \%$ of them demonstrated the symptom in a dominant phase. The average score in the group of students with symptoms of anxiety and depression was 7.4 points. $57.2 \%$ of respondents had a mature symptom; in $35.7 \%$ of cases the symptom was of complex nature and $7.1 \%$ of the students had immature symptom.

Resistance in students-psychologists was expressed in the following way (the average score was 39.9 points): $42.9 \%$ of the respondents demonstrated immature phase; $21.4 \%$ of the group participants had mature phase and in $35.7 \%$ of respondents the symptom was in the process of formation. The average score in the group of students with the symptoms of inadequate selective emotional response was 12.8 points. In particular, $42.9 \%$ of the surveyed had immature symptom; $21.4 \%$ demonstrated complex nature of the symptom; $7.1 \%$ of students had mature symptom and in $28.6 \%$ of cases the symptom was in its dominant phase. The average score in the group of study participants with the symptoms of emotional and moral disorientation amounted to 8.9 points. $71.4 \%$ of respondents had mature symptom; $14.3 \%$ of the surveyed had the symptom of complex nature and in $14.3 \%$ of cases the symptom was dominant. The average score in the group of students with symptoms of expanding the sphere of emotional thriftiness was 6.4 points. $78.6 \%$ of the surveyed had mature symptom; $14.3 \%$ of them demonstrated complex nature of this symptom and among $7.1 \%$ of the students the symptom was dominant. The average score in the group of students with the symptom of professional duties reduction was 11.8 points. In particular, $50 \%$ of the surveyed had mature symptom; $14.3 \%$ demonstrated complex nature of the symptom; in $14.3 \%$ of respondents the symptom was immature and among $21.4 \%$ of study participants the symptom was dominant.

Exhaustion of students-psychologists was expressed in the following way (the average score was 28.9 points): $64.3 \%$ of the surveyed demonstrated immature phase; $35.7 \%$ of respondents were characterized by forming phase. The average score in the group of students with symptoms of emotional deficit was 8.1 points. In particular, $57.2 \%$ of the surveyed had mature symptom; $35.7 \%$ of the group demonstrated complex nature of the symptom and $7.1 \%$ demonstrated immature symptom. The average score in the group of students with symptoms of emotional detachment was 10.8 points. $28.6 \%$ of the group had mature symptom; $42.8 \%$ demonstrated the symptom of complex nature; $14.3 \%$ of respondents demonstrated immature symptom and among $14.3 \%$ of the surveyed the symptom was dominant. The average score in the group of study participants demonstrating the symptoms of personal detachment or depersonalization was 4.9 points. $78.6 \%$ of the surveyed had mature symptom and $21.4 \%$ of respondents demonstrated complex nature of the symptom. The average score in the group of study participants with the symptoms of psychosomatic and psycho-vegetative disorders was 5.1 points. $85.7 \%$ of the respondents had mature symptom and $14.3 \%$ of the group demonstrated complex nature of the symptom.

Thus, the vast majority of students-psychologists demonstrate high and a relatively high level of emotional burnout; the minority of them were characterized by the small and medium level of emotional burnout.

Conclusions and prospects for further research. Burnout syndrome is considered as a process of gradual loss of emotional, cognitive and physical energy, which is manifested in the symptoms of emotional, mental exhaustion, physical fatigue, personal detachment and dissatisfaction with work performance. The study has shown that $30 \%$ of professional psychologists demonstrate high level of emotional burnout and among $30 \%$ of them the level of emotional burnout is higher than average. As for studentspsychologists, $10 \%$ of them are characterized by high level of emotional burnout. The results obtained are quite worrying as long as this tendency is expected to progress without specially organized psychoprophylactic and psychocorrective work. Prospects for further research involve 
the study of the influence of self-esteem level on emotional burnout. We are planning to develop a special diagnostic and correctional programme intended to the stabili-

\section{ЛІТЕРАТУРА}

1. Сидоров П. Синдром емоційного вигорання / П. Сидоров // Медична газета. - № 43. - С. 12-15.

2. Макарова Г. А. Синдром емоційного вигорання [Електронний ресурс] / Г. А. Макарова. - Режим доступу : www.psyinst.ru/library.php?part=article\&id=2.

3. Ильин Е. П. Психофизиология состояний человека /

Е. П. Ильин. - СПб. : Питер, 2005. - С. 233-236.

4. Орел В. Є. Феномен «вигорання» у закордонній психології : емпіричні дослідження і перспективи / В. С. Орел // Психологический журнал. 2001. - № 1. - C. 90-101.

5. Arthur N. M. The assessment of burnout: a review of three inventories useful for research and counseling / N. M. Arthur // Journal of Counseling and Development.

\section{REFERENCES}

1. Sydorov, P. Syndrom emotsiinoho vyhorannia [Emotional burnout syndrome]. Medychna hazeta - Medical journal, 43, 12-15 [in Ukrainian].

2. Makarova, H. A. Syndrom emotsiinoho vyhorannia [Emotional burnout syndrome]. Retrieved from: www.psyinst.ru/library.php?part=article\&id=2 [in Ukrainian].

3. Ilin, Ye. P. (2005). Psikhofiziologiya sostoyaniy cheloveka [Psychophysiology of human states]. (pp. 233236). St. Petersburg: Piter [in Russian].

4. Orel, V. Ye. (2001). Fenomen «vyhorannia» u zakordonnii psykholohii: empirychni doslidzhennia i perspektyvy [The phenomenon of burnout in foreign psychology: empirical research and prospects]. Psikhologicheskiy zhurnal - Psychological journal, 1, 90-101 [in Ukrainian].

5. Arthur, N. M. (1990). The assessment of burnout: a review of three inventories useful for research and zation of professional psychologists' emotional states as well as reducing emotional burnout level and implement it into school work in the city of Melitopol.

- 1990. - Vol. 69. - P. 186-189.

6. Leiter M. P., Maslach C. Banishing burnout: six strategies for improving your relationship with work. Jossey-Bass, A Wiley Imprint, 2005. - 193 p.

7. Maslach C. M. Job burnout: new directions in research and intervention / C. M. Maslach // Current Directions in Psychological Science. - 2003. - Vol. 12. - P. 189-192.

8. Maslach C. M., Schaufeli W. B., Leiter M. P. Job burnout / C. M. Maslach, W. B. Schaufeli, M. P. Leiter // Annual Review of Psychology. - 2001. - Vol. 52. - P. 397-422.

9. Водопьянова Н. Е., Старченкова Е. С. Синдром выгорания: диагностика и профилактика / Н. Е. Водопьянова, Е. С. Старченкова. - СПб. : Питер, 2008. - С. 109-113.

counseling. Journal of Counselling and Development. (Vols. 69). (pp. 186-189) [in English].

6. Leiter, M. P., \& Maslach, C. M. (2005). Banishing burnout: six strategies for improving your relationship with work. Jossey-Bass, A Wiley Imprint [in English].

7. Maslach, C. M. (2003). Job burnout: new directions in research and intervention. Current Directions in Psychological Science. (Vols. 12). (pp. 189-192) [in English].

8. Maslach, C. M., Schaufeli, W. B., \& Leiter, M. P. (2001). Job burnout. Annual Review of Psychology. (Vols. 52). (pp. 397-422) [in English].

9. Vodopyanova, N. Ye., \& Starchenkova, Ye. S. (2008). Sindrom vygoraniya: diagnostika i profilaktika [Burnout syndrome: diagnostics and preventive measures]. (pp.109-113). St. Petersburg: Piter [in Russian].

$$
\begin{array}{r}
\text { Ольга Вікторівна Царькова, } \\
\text { кандидат психологічних наук, доцент кафедри психологї̈, } \\
\text { Олеся Олексіївна Прокоф'єва, } \\
\text { кандидат психологічних наук, доцент кафедри психологї̈, } \\
\text { Ольга Анатоліївна Прокоф'єва, } \\
\text { стариий викладач кафедри анатомії і фізіології людини і тварин, } \\
\text { Мелітопольський державний педагогічний університет імені Богдана Хмельницького, }
\end{array}
$$
вул. Леніна, 20, м. Мелітополь, Україна

\section{ДОСЛІДЖЕННЯ ЕМОЦИЙНОГО ВИГОРАННЯ У \\ СТУДЕНТІВ-ПСИХОЛОГІВ І ПСИХОЛОГІВ-ПРОФЕСІОНАЛІВ}

Статтю присвячено виявленню рівня емоційного вигорання серед студентів-психологів та психологівпрофесіоналів. Робота психолога часто пов'язана з тривалими стресами у сфері міжособистісного спілкування, зумовленими значною відповідальністю за встановлення довірливих стосунків, необхідністю вміти керувати емоційною напруженістю спілкування. Як наслідок, психолог може зазнати стану емоційного та фізичного виснаження, емоційної відстороненості, втрати енергії та ін. Визначено, що емоційне вигорання - це вироблений особистістю механізм психологічного захисту у формі повного або часткового виключення емоцій у відповідь на психотравмуючі впливи. Синдром вигорання - це процес поступової втрати емоційної, когнітивної та фізичної енергії, що виявляється в симптомах емоційного, розумового виснаження, фізичного стомлення, особистісної відстороненості та зниження задо- 
волення виконанням роботи. Такі стани неодмінно позначаються на фізичному та психічному здоров ї психолога, а також на його відношенні до професійних обов'язків та якості їх виконання. У дослідженні рівня емоційного вигорання взяли участь студенти 3-4 курсів спеціальності «Психологія», а також практикуючі психологи. Емпіричне дослідження рівня емоційного вигорання складалося з визначення ступеня вираженості таких симптомів емоційного вигорання, як напруга, тривога і депресія, емоційна та моральна дезорієнтація, економія емоцій, виснаження, емоційна відстороненість, деперсоналізація та ін. Проведене нами дослідження показало, що емоційне вигорання у 30 \% психологів-професіоналів знаходиться на високому рівні, а ще у 30 \% на рівні вище середнього. Серед студентівпсихологів 10\% мають високий рівень емоційного вигорання. Такі показники є досить тривожними, тому що без спеціально організованої психопрофілактичної та психокорекційної роботи виявлена тенденція може прогресувати. Перспективою подальших досліджень $є$ вивчення впливу рівня самооцінки на рівень емоційного вигорання. Планується розробка і впровадження у практику роботи шкіл міста Мелітополь та Мелітопольского району спеціальної діагностично-корекційної програми, спрямованої на стабілізацію емоційного стану психологів-професіоналів, зниження рівня емоційного вигорання.

Ключові слова: синдром емоційного вигорання, студенти-психологи, психологи-професіонали, стрес, симптоми емоційного вигорання.

Ольга Викторовна Царькова, кандидат психологических наук, дочент кафедры психологии,

Олеся Алексеевна Прокофьева, кандидат психологических наук, дочент кафедры психологии,

Ольга Анатольевна Прокофьева,

старший преподаватель кафедры анатомии и физиологии человека и животных, Мелитопольский государственный педагогический университет имени Богдана Хмельницкого, ул. Ленина, 20, г. Мелитополь, Украина

\section{ИССЛЕДОВАНИЕ ЭМОЦИОНАЛЬНОГО ВЫГОРАНИЯ \\ СТУДЕНТОВ-ПСИХОЛОГОВ И ПСИХОЛОГОВ-ПРОФЕССИОНАЛОВ}

Статья посвящена выявлению уровня эмоционального выгорания среди студентов-психологов и психологовпрофессионалов. Работа психолога часто связана с длительными стрессами в сфере межличностного общения, обусловленными значительной ответственностью за установление доверительных отношений, необходимостью уметь управлять эмоциональной напряженностью общения. Как следствие, психолог может испытывать состояния эмоционального и физического истощения, эмоциональной отстраненности, потери энергии и др. Определено, что эмоциональное выгорание - это выработанный личностью механизм психологической защиты в форме полного или частичного отсутствия эмоций в ответ на психотравмирующие воздействия. Синдром выгорания - это процесс постепенной утраты эмоциональной, когнитивной и физической энергии, проявляющийся в симптомах эмоционального, умственного истощения, физического утомления, личностной отстраненности и снижения удовлетворения выполнением работы. Такие состояния непременно сказываются на физическом и психическом здоровье психолога, а также на его отношении к профессиональным обязанностям и качестве их выполнения. В исследовании уровня эмоционального выгорания приняли участие студенты 3-4 курсов специальности «Психология», а также практикующие психологи. Эмпирическое исследование уровня эмоционального выгорания включало определение степени выраженности таких симптомов эмоционального выгорания, как напряжение, тревога и депрессия, эмоциональная и моральная дезориентация, экономия эмоций, истощение, эмоциональная отстраненность, деперсонализация и др. Проведенное исследование показало, что эмоциональное выгорание у 30\% психологов-профессионалов находится на высоком уровне, а еще у $30 \%$ - на уровне выше среднего. Среди студентов-психологов 10\% имеют высокий уровень эмоционального выгорания. Такие показатели вызывают тревогу, поскольку без специально организованной психопрофилактической и психокоррекционной работы выявленная тенденция может прогрессировать. Перспективой дальнейших исследований является изучение влияния уровня самооценки на уровень эмоционального выгорания. Планируется разработка и внедрение в практику работы школ города Мелитополь и Мелитопольского района специальной диагностико-коррекционной программы, направленной на стабилизацию эмоционального состояния психологов-профессионалов, снижение уровня эмоционального выгорания.

Ключевые слова: синдром эмоционального выгорания, студенты-психологи, психологи-профессионалы, стресс, симптомы эмоционального выгорания.

Подано до редакиії 08.02.2016

Рецензент: д. психол. н. В. В. Зарицька 